DOI: https://doi.org/10.47405/mjssh.v6i4.743

\begin{tabular}{|c|c|}
\hline$m_{1}=$ & Malaysian Journal of Social Sciences and Humanities (MJSSH) \\
\hline Malaysian Journal of & Volume 6, Issue 4, April 2021 \\
\hline (MJ-SSH) & e-ISSN : 2504-8562 \\
\hline & $\begin{array}{l}\text { Journal home page: } \\
\text { www.msocialsciences.com }\end{array}$ \\
\hline
\end{tabular}

\title{
Komunikasi dalam Adaptasi Antara Budaya Tenaga Kerja Indonesia di Malaysia
}

Melly Ridaryanthi ${ }^{1}$

1Universitas Mercu Buana, Indonesia

Correspondence: Melly Ridaryanthi (m.ridaryanthi@gmail.com)

\begin{abstract}
Abstrak
Kajian ini melihat pengalaman komunikasi dan adaptasi antara budaya Tenaga Kerja Indonesia (TKI) di Malaysia. Penghijrahan TKI ke Malaysia yang berlaku terus menerus penting untuk dikaji daripada sudut pandang ilmu komunikasi. Keberadaan TKI sebagai pendatang tidak dapat dielakkan dari terwujudnya interaksi dan komunikasi dalam kehidupan sehari-hari di negara tuan rumah. Untuk itu, kajian ini meneroka pengalaman komunikasi dan adaptasi TKI di negara destinasi dengan menjalankan kajian kualitatif dengan perbincangan kumpulan fokus dan temu bual mendalam untuk kajian lapangan. Didapati bahawa interaksi dan komunikasi TKI dalam penghijrahan wujud antara sesama TKI penghijrah, antara TKI dengan keluarga di tanah air, antara TKI dengan masyarakat tuan rumah dan komunikasi melalui penggunaan media. Diketahui bahawa pendedahan ke atas media massa memberikan kesan ke atas pembentukan persepsi, stereotaip dan bahkan prejudis dalam interaksi sehari-hari. Sebagai kesannya, masyarakat tuan rumah cenderung membangun interaksi dengan TKI pada permukaan sahaja. Kesan daripada pengalaman bekerja di luar negara dihuraikan sebagai gambaran bagaimana mereka melalui pengalaman penghijrahan mereka di rantau dalam proses adaptasi antara budayanya.
\end{abstract}

Kata kunci: tenaga kerja Indonesia, komunikasi, interaksi, adaptasi antar budaya

\section{Communication and Intercultural Adaptation of Indonesian Migrant Workers in Malaysia}

\begin{abstract}
This study sought the communication and intercultural adaptation experience of Indonesian Migrant Workers (TKI) in Malaysia. The migration of TKI to Malaysia has been continuously happening, thus it is important to study this phenomenon from the perspective of communication study. Interaction and communication between TKI and local citizen cannot be avoided. Thus, this study aims to explore the communication and adaptation experience among TKI in the destination country. This study employed qualitative approach with focus group discussion and in depth interview as data gathering methods. The findings show that interaction and communication in TKI migration occur between TKIs, TKIs and their respective family in the home country, TKI s with local citizen as well as the use of media during migration. The exposure towards media has affected the construction of perception, stereotype and even prejudice in daily interaction. As the consequences, host citizen develop their interaction with TKIs in the surface manner. Their working experience in the host country has given picture how they gone through their intercultural adaptation process.
\end{abstract}


Keywords: Indonesian migrant workers, communication, interaction, intercultural adaptation

\section{Pengenalan}

Penghijrahan penduduk dunia tidak terjadi hanya dalam satu atau dua dekad ini sahaja. Ianya telah berlangsung dalam beberapa gelombang sekitar awal abad ke-17 (Weiner, 1995). Dengan begitu, pergerakan penduduk dunia telah wujud daripada zaman semasa teknologi komunikasi dan pengangkutan belum canggih seperti sekarang. Dunia global dan perkembangannya sentiasa membawa perubahan ke atas beberapa aspek seperti demografi, pembangunan dan demokrasi sesebuah negara yang boleh membawa pada perkembangan rangkaian sosial dan migrasi pada industri global (Hugo, 2006; Gozzini, 2006). Bahkan beberapa sarjana melihat penghijrahan sebagai satu proses melingkar di mana perubahan dalam masyarakat dunia wujud sebagai sesuatu yang dinamik dan pekerja migran tidak lagi dilihat sebagai tetamu, tetapi sebagai ciri masa depan sebuah masyarakat sosial (Vertovec, 2007; Schierup et al., 2006).

Penghijrahan penduduk terjadi kerana adanya perbezaan dari beberapa faktor dalam sesebuah negara seperti pola pembangunan, tenaga kerja, tingkat pendapatan dan kemiskinan (Hugo, 2006). Krisis ekonomi yang melanda sesebuah negara membawa pada pergerakan penduduk untuk tujuan bekerja ke luar negara yang bukan sahaja menguntungkan bagi individu-individu yang berhijrah sebagai pekerja, tetapi juga bagi negara destinasi yang juga mendapatkan keuntungan daripada pergerakan tenaga kerja ini (Firdausy, 2005; Fix et al., 2009). Di negara destinasi penghijrahan, selalunya terdapat dua golongan pasar pekerjaan iaitu kumpulan primer yang diperuntukkan bagi warga tempatan dan juga kumpulan menengah dengan pekerjaan yang masuk dalam kategori ' 3 -D' iaitu dirty, dangerous, difficult (kotor, berbahaya, sukar) biasanya menjadi matlamat kedatangan para pekerja migran. Dengan berlangsungnya mobiliti penduduk memberikan keuntungan bersama bagi negara yang mempunyai banyak tenaga kerja menganggur ke negara yang kekurangan (Gozzini, 2006). Aliran tenaga kerja/buruh dari negara-negara dengan jumlah penduduk yang besar sangat membantu pembangunan di negara-negara destinasi yang sememangnya mengalami kekurangan tenaga kerja pada sektor-sektor tidak rasmi yang termasuk dalam golongan pekerjaan '3-D' itu.

Penghijrahan tenaga kerja ke seluruh dunia yang berasal daripada negara yang kaya tenaga pekerja menuju negara yang miskin tenaga pekerja akan terus berlaku (Landis, 2008). Penghijrahan penduduk ini tidak terlepas daripada globalisasi di mana pelbagai aspek kehidupan berkembang termasuk pula teknologi komunikasi dan pengangkutan. Dikatakan oleh Kim dan Bhawuk (2008) bahawa globalisasi telah membawa kepada perubahan maklumat dan saling komunikatif di antara individu-individu di seluruh dunia sehingga terjadi perubahan yang pantas ke atas pelbagai bidang kehidupan manusia; sosial, ekonomi, dan lain-lain. Dengan begitu, individu-individu saling bergantung antara satu dan yang lainnya dalam skala global. Perkembangan yang terjadi ini menjadi punca daripada pelbagai peluang untuk mencapai kehidupan yang lebih baik, salah satunya adalah daripada segi ekonomi (Fix et al., 2009). Tidak hairan bahawa terjadi peningkatan jumlah pekerja di beberapa negara selari dengan aktiviti penghijrahan penduduk dunia ini.

Sementara itu, penghijrahan penduduk di wilayah Asia merupakan sambutan ke atas perubahan dalam masyarakat global, hal ini berhubung kait dengan perubahan yang besar-besaran dan pantas dalam pelbagai aspek kehidupan pada era globalisasi (Hugo, 2006). Globalisasi membabitkan peningkatan daripada segi aliran modal, barangan, perkhidmatan dan perkembangan teknologi maklumat daripada negara-negara yang terbabit. Selain daripada itu juga, globalisasi telah membabitkan individu-individu melalui mobiliti merentasi sempadan yang tidak pernah berkurang.

Di antara elemen-elemen yang menyebabkan motivasi penghijrahan adalah seperti murahnya tambang pengangkutan ke luar negara, perubahan polisi, ada celah antara negara-negara yang kekurangan dan kelebihan tenaga kerja sebagai peluang untuk bekerja, kesan globalisasi pada pertukaran barang, maklumat dan lainnya yang menggalakkan mobiliti bilangan penduduk dunia, dan juga pertumbuhan 
negara-negara di Asia Tenggara adalah beberapa faktor yang menjadi punca wujudnya migrasi tenaga kerja (Hugo 2004).

Sebagai masyarakat dengan latar budaya kolektif yang berakar pada budaya Melayu, penghijrah dan tuan rumah pada kajian ini sepintas lalu dipandang sebagai kumpulan budaya yang sama. Kemiripan ciri fizikal, bahasa, pemakanan dan amalan budaya-budaya harian melahirkan pandangan bahawa kedua kumpulan budaya ini akan mudah untuk berinteraksi. Seperti dikatakan oleh Dementeva et al (2015) bahawa terdapat kedekatan hubungan antara individu-individu dalam masyarakat dengan latar budaya kolektif, sehingga mesej dalam komunikasi dianggap tidak perlu disampaikan dengan rinci. Individu-individu yang terbabit dalam komunikasi dalam budaya kolektif biasanya menjangka maklumat yang diterima berdasarkan pada konteks keadaan dan berdasarkan maklumat sebelumnya yang mereka ketahui. Pada kenyataannya, penghijrahan TKI ke Malaysia ini menimbulkan cabarancabaran bagi individu-individu yang terbabit dalam interaksi seharian sebagai kesan daripada percanggahan budaya yang diperkongsikan melalui aktiviti komunikasi.

Pada penghijrahan Tenaga Kerja Indonesia (TKI) ke Malaysia, terdapat dua kumpulan masyarakat yang terbabit dalam komunikasi sehari-hari iaitu kumpulan penghijrah dan tuan rumah. Seperti dinyatakan oleh $\operatorname{Kim}(1977,1988,2001,2007)$ bahawa dalam penghijrahan wujud komunikasi antara budaya meliputi komunikasi intra-etnik, antar-etnik dan antar-kumpulan. Interaksi sosial dalam masyarakat boleh menunjukkan hubungan yang muncul antara individu dan kumpulan dalam masyarakat berdasarkan pada jarak, pemisahan, pengasingan, kerjasama, rakan kongsi, pertemanan, konflik, dan lain sebagainya (Gsir, 2014). Dalam kajian ini, penyelidik mengkategorikan beberapa kumpulan masyarakat berdasarkan pada karakteristik dan aktiviti komunikasi yang berlangsung di antara mereka.

Pada kumpulan penghijrah, terjadi pengelompokkan semula berdasarkan pada jenis pekerjaan dan etnik atau daerah asal. Sementara itu masyarakat tuan rumah dapat diagihkan menjadi dua kumpulan budaya iaitu kumpulan tuan rumah yang mengupah TKI iaitu sebagai majikan dan kumpulan tuan rumah secara am berdasarkan pada kepelbagaian etnik. Kumpulan-kumpulan budaya ini dikenali melalui pengalaman interaksi dan komunikasi TKI dan masyarakat tuan rumah.

\section{Sorotan Literatur}

Penghijrahan antarabangsa ini membabitkan individu-individu yang berlatar budaya berbeza dari masyarakat tuan rumah, sehingga berkesan ke atas kepelbagaian budaya di negara destinasi. Kim (1977) meneroka komunikasi yang wujud dalam penghijrahan dan mengkategorikannya ke dalam dua kumpulan komunikasi iaitu intra-etnik dan inter-etnik. Jumlah populasi penghijrah yang cukup tinggi menyebabkan interaksi antara pendatang dan tuan rumah tidak dapat dielakkan lagi. Sehingga komunikasi harian antara kedua-dua kumpulan masyarakat pendatang dan tuan rumah menjadi lebih kompleks. Selain daripada itu, Ketab et al. (2015) merangkumi beberapa kajian banyak sarjana bahawa hubungan inter-etnik dalam masyarakat dengan latar kepelbagaian budaya boleh memberikan kesan pada rasa kebersamaan, konsep kendiri sosial yang lebih baik dan meningkatkan pemahaman budaya.

Komunikasi dan budaya merupakan dua hal yang saling berhubung kait. Dengan wujudnya komunikasi dalam suatu persekitaran, maka dimungkinkan terjadinya perkongsian budaya yang diamalkan oleh setiap individu yang terbabit di dalamnya. Secara epistemologi, kajian komunikasi antara budaya melihat bagaimana proses interaksi dalam mengenal imej diri sendiri, bagaimana individu-individu dari budaya lain berpikir tentang diri kita, dan siapakah mereka yang berasal daripada budaya lain itu? Seperti dikatakan oleh Gudykunst dan Kim (2003) "the more important our group memberships are to how we define ourselves, the greater our predictive certainty regarding strangers' behavior" iaitu semakin kita boleh menetapkan takrifan ke atas diri dan kumpulan, semakin tepat ramalan kita ke atas perilaku orang lain (asing). Dengan kata lain, dalam berinteraksi dengan orang-orang yang berasal daripada budaya berbeza, mesti dipastikan bahawa kita (dan kumpulan 
budaya kita sendiri) boleh dengan pasti menetapkan konsep diri sehingga komunikasi antara budaya yang berlangsung dalam interaksi sehari-hari lebih berkesan.

\section{Komunikasi dalam Penghijrahan}

Dalam penghijrahan, antara penghijrah dan persekitaran budaya tamu memiliki hubung kait satu sama lain. Komunikasi antara individu dengan persekitarannya adalah bahagian penting daripada pengalaman penghijrahan itu. Interaksi individu tidak hanya wujud dalam kalangan kumpulan budayanya sendiri sahaja, tetapi juga dengan kumpulan budaya tuan rumah. Malahan, menurut Kim (2008) kekuatan kumpulan budaya boleh masuk campur atau menjadi pengantara antara hubungan para pendatang dengan persekitaran tuan rumah. Sehingga, persekitaran pada dasarnya memberikan pengaruh besar ke atas aktiviti komunikasi harian individu.

Rajah yang tersedia menggambarkan bahawa persekitaran budaya tamu boleh memberikan kesan ke atas komunikasi individu. Difahami bahawa hubungan antara persekitaran dan komunikasi dalam penghijrahan. Difahami bahawa keterbukaan dan tekanan yang diberikan oleh masyarakat tuan rumah boleh mempengaruhi kecekapan komunikasi penghijrah mengikut komunikasi tuan rumah. Sementara kedekatan penghijrah dengan kumpulan etniknya yang lebih dominan berbanding kedekatan individu dengan kumpulan etnik tuan rumah boleh menyukarkan kecekapan komunikasi mengikut komunikasi tuan rumah ini. Manakala, kekuatan hubungan dalam kumpulan etnik penghijrah boleh memperkukuhkan lagi komunikasi kumpulan dalaman penghijrah semasa berada di negara destinasi.

\section{Rajah 1: Hubungan antara Persekitaran dan Konstruksi Komunikasi dalam Penghijrahan}

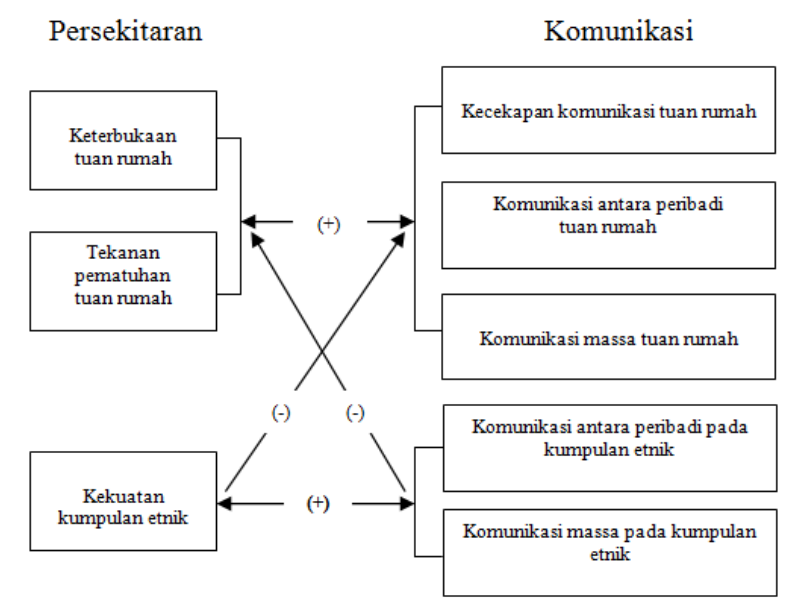

Sumber: Kim (2008)

Melalui interaksi dengan persekitaran, perkongsian budaya boleh wujud sehingga komunikasi berlangsung semakin kompleks. Apalagi, melalui komunikasi wujud penghantaran dan penafsiran daripada simbol-simbol budaya yang wujud dalam persekitaran. Dengan begitu, tingkat kesukaran dalam membuat tafsiran dan persepsi ke atas mesej yang diterima lebih tinggi mengingat rangka acuan yang digunakan adalah berbeza. Komunikasi antara individu yang dilatari dengan kepelbagaian budaya ini dikenali dengan komunikasi antara budaya. Rajah di atas menjadi panduan dalam penerokaan ke atas pengalaman interaksi dan komunikasi TKI dan tuan rumah pada kajian ini.

\section{Komunikasi Antarabudaya}

Komunikasi adalah proses yang rumit. Aspek mesej yang disampaikan dalam komunikasi pun pelbagai; sama ada ianya bersifat langsung mahupun tidak langsung, verbal mahupun bukan verbal, kesemuanya menentukan bagaimana proses komunikasi itu berlangsung. Komunikasi verbal merujuk pada penggunaan bahasa tertulis mahupun lisan yang dikongsikan, di mana bahasa memainkan peranan yang amat penting dalam jenis komunikasi ini. Sementara itu, komunikasi non-verbal adalah 
aktiviti komunikasi di luar bahasa yang melibatkan perasaan, perilaku, gerakan, nada bicara dan lain sebagainya yang dipengaruhi oleh konteks, budaya dan tujuan dari aktiviti komunikasi itu (Albert et al., 2012). Sementara itu, komunikasi antara budaya adalah proses transaksi simbolik yang melibatkan pertukaran makna antara individu-individu yang berasal dari latar budaya yang berbeza (Gudykunst \& Kim, 1997, Lustig \& Koester, 2013). Klyukanov (2005) merumuskan bahawa komunikasi antara budaya adalah serangkaian proses interaksi antara kumpulan-kumpulan individu yang memiliki sistem simbolik berbeza antara satu dengan yang lainnya. Dalam komunikasi antara budaya, individu berkongsi sistem simbol-simbol verbal dan bukan verbal yang mempunyai makna ke atas ahli dalam suatu kumpulan masyarakat (Fong, 2004 dalam Klyukanov 2005). Komunikasi yang berkesan berlaku apabila individu mencapai persefahaman, merangsang yang lain bertindak, dan mendorong orang lain untuk berfikir dengan cara yang baru (Kholisoh et al., 2017). Cara ini amatlah penting dalam konteks adaptasi antara budaya.

Istilah 'antara budaya' biasanya digunakan untuk menjelaskan sekurang-kurangnya terdapat dua orang yang berbeza budaya (Lustig \& Koester, 2013). Ketika istilah 'komunikasi antara budaya' digunakan, hal ini tidak harus bermakna bahawa suatu aktiviti komunikasi itu harus efektif. Hal ini disebabkan kerana individu-individu yang terbabit dalam komunikasi antara budaya sudah tentu memiliki latar budaya yang berbeza sehingga boleh dipastikan bahawa di antara mereka tidak ada kesefahaman makna. Dalam ayat lain, komunikasi antara budaya membabitkan rangka rujukan yang berbeza-beza seperti kepercayaan, nilai, norma, aturan dan sebagainya, sehingga penerima mesej mungkin sahaja salah membuat tafsiran.

Gudykunst (2004) mengatakan bahawa salah tafsiran ini boleh terjadi disebabkan oleh beberapa hal seperti mesej yang disampaikan tidak boleh difahami oleh individu lain disebabkan oleh struktur bahasa yang berlainan contohnya. Selain daripada itu, kaedah-kaedah komunikasi antara individuindividu yang terbabit adalah berbeza, sehingga boleh mempengaruhi proses penyampaian dan interpretasi mesej. Orang-orang dari budaya yang berbeza mempunyai perbezaan satu sama lain yang boleh menyebabkan perbezaan tafsiran dan harapan mengenai apa yang dianggap sebagai perilaku komunikasi yang cekap (Lustig \& Koester, 2013). Ditambahkan lagi bahawa komunikasi antara budaya wujud ketika orang-orang yang memiliki perbezaan itu menciptakan tafsiran dan pengharapan mengenai bagaimana cara berkomunikasi dengan cekap dalam persekitarannya.

Martin dan Nakayama (2011) berpandangan bahawa wujud perubahan tren penghijrahan manusia yang semakin aktif berkesan sehingga pada interaksi pada sesebuah kawasan sehingga membuka peluang dan cabaran bagi individu-individu yang terbabit di dalamnya; sama ada itu mereka yang hendak berhijrah, atau pun mereka yang terbabit interaksi dengan penghijrah. Komunikasi antara budaya menggambarkan suatu bentuk interaksi manusia yang penting di mana setiap individu dapat mengatasi perbezaan yang ada pada setiap budaya individu masing-masing (Samovar, 2006). Aktiviti komunikasi dengan orang-orang yang berlainan etnik boleh mengurangi jarak sosial antara kumpulan budaya dalam suatu masyarakat (Choney, 2015). Dalam hal ini berhubung kait dengan komunikasi antara budaya yang berlaku antara individu-individu dengan latar budaya yang berbeza-beza. Termasuk juga dalam penggunaan media yang dapat berkaitan dengan konstruksi identiti seseorang (Briandana, 2019). Komunikasi antara budaya sangat rapat hubung kaitannya dengan adaptasi yang dilakukan para penghijrah antara budaya kerana proses adaptasi yang dilakukan tidak akan terlepas dari peranan komunikasi di dalamnya.

\section{Metod Kajian}

Penerokaan pada kajian komunikasi dan adaptasi antarabudaya yang merupakan bahagian daripada kajian budaya menekankan dapatan kajian pada konteks sosial dengan menekankan nilai kesahan pada konteks, dialog dan cerminan diri (Saukko, 2005, 2008). Konteks dalam sesebuah kajian yang menyoroti fenomena sosial dapat dicapai dengan wujudnya kajian yang mendekat pada subjek kajian dengan pelaksanaan temubual atau pemerhatian secara langsung. Kajian ini menggunakan pendekatan kualitatif dengan menjalankan temubual kumpulan fokus ke atas Tenaga Kerja Indonesia yang bekerja pada bidang khidmat kebersihan, pembuatan di kilang dan pembinaan di kawasan Lembah Klang, 
Malaysia. Selain itu, temubual mendalam dijalankan ke atas masyarakat tuan rumah dalam dua kategori; (i) masyarakat umum yang tidak pernah mengupah TKI dan (ii) masyarakat tuan rumah yang pernah mengupah TKI.

\section{Hasil Kajian dan Perbincangan}

\section{Interaksi dan Komunikasi Sesama Penghijrah}

Interaksi TKI di negara destinasi wujud dalam kalangan sesama pekerja migran asal Indonesia. Hal ini dikesan oleh wujudnya kedekatan kekerabatan di antara mereka, kedekatan etnik dan budaya asal, persamaan nasib dan tujuan sebagai pekerja migran. Diketahui bahawa sebahagian TKI yang berhijrah datang dengan mengikuti kerabat mereka yang sudah lebih dahulu berhijrah ke Malaysia. Sebagai sesama pekerja migran asal dari Indonesia, masing-masing informan memiliki kedekatan budaya satu sama lain. Apatah lagi mereka yang memiliki ikatan kekerabatan, ikatan etnik mereka kuat. Dengan persamaan motivasi berhijrah, para informan melihat kesamaan nasib dan tujuan mereka dalam berhijrah, hal ini melatari kewujudan interaksi dan komunikasi mereka di rantau.

Sebagai contoh, Didin salah satu TKI yang membawa kedua-dua anak perempuannya ke Malaysia, membawa mereka ikut menjadi TKI dengan bekerja di Kilang dan di kedai makan yang berhampiran dengan tempat tinggalnya. Mereka tinggal bersama-sama dalam satu rumah dengan beberapa TKI yang berasal dari kampung yang sama di negara asal. Dengan begitu, ikatan kekeluargaan TKI ini terbawa sehingga ke tanah rantau. Tidak hairan jika didapati beberapa kawasan di Malaysia sebagai tempat tinggal sekumpulan orang Indonesia dengan etnik tertentu. Diawali dengan berhijrah sendiri, berkelompok, mengajak sanak keluarga dan kemudian tinggal secara tetap adalah pola berkembangnya sejumlah penduduk migran di Malaysia.

\section{"Anak ada di sini, kedua-duanya di sini. Kedua-duanya perempuan. Kerja, yang satu keluarga di sate kajang, di Sate Kajang Haji Samuri, yang satu di kedai makanan di (Restoran) Lyus. " (Didin - Kilang)}

Dalam pengurusan tempat tinggal pula, seperti yang telah dijelaskan pada sub bab sebelum ini, diketahui bahawa tempat tinggal TKI selama di Malaysia memberi peluang kepada mereka untuk berinteraksi dengan sesamanya lebih kerap; bekerja di tempat yang sama, tinggal di rumah dan di kawasan yang sama. Namun, interaksi informan TKI dengan kumpulan etniknya tidak hanya sebatas dengan keluarga dan rakan sekerja mereka sahaja. Ada kalanya para informan pergi ke tempat-tempat yang biasa dikunjungi TKI untuk menikmati masa cuti mereka. Kawasan seperti Kampung Baru dan Chow Kit adalah di antara kawasan di mana biasanya mereka membangun pertemanan baru dengan sesama pekerja migran asal Indonesia yang tinggal di kawasan lain. Kadang-kadang juga mereka akan hadiri acara-acara yang dibuat oleh Kedutaan di Kuala Lumpur, di mana mereka boleh berkumpul dengan para TKI dari pelbagai kawasan di Malaysia.

\section{“...Ya sering juga (pergi ke KL). Bertemu sama orang Medan kah, orang Jawa kah (sesama penghijrah)...” (Abah-Kilang) \\ “...Kalau paguyuban (kumpul dengan sesama etnik) kita ikut.” (Wawan - Pembinaan)}

Dalam interaksi sehari-hari, para TKI biasa berkomunikasi menggunakan pelbagai bahasa yang membuat mereka selesa. Melalui perbincangan didapati bahawa bahasa Indonesia, bahasa daerah mahupun bahasa Melayu digunakan secara bercampur-campur dalam komunikasi sehari-hari. Eratnya ikatan antara etnik dalam penghijrahan ini memberikan ruang bagi mereka untuk terus mengekalkan penggunaan bahasa dan budaya daerah asal.

“...kalau di sini memang kebanyakan pakai basa Sunda saja. Kebanyakannya basa Sunda di sini (di Kilang)." (Abah - Kilang) 


\author{
“...ya sama orang Indon (Indonesia, berinteraksi). Saya sukanya (berinteraksi) \\ sama orang Indon." (Esah - Khidmat Kebersihan \\ “...saya di sini banyak kawan orang jawa jadi cakap pun masih cakap bahasa jawa. \\ Kita ngomong melayu hanya dengan orang melayu saja. Kita tetep teguh sama \\ tradisi kita..." (Rumini - Khidmat Kebersihan) \\ “...ya adalah sedikit orang yang membezakan antara Madura dengan Jawa...” (Sari \\ - Khidmat Kebersihan)
}

Didapati bahawa dalam interaksi sehari-hari mereka juga wujud perbezaan-perbezaan berdasarkan latar etnik TKI. Pada kumpulan TKI pekerja kilang dan khidmat kebersihan, mereka tidak mengambil kira perbezaan etnik ini dalam interaksi sehari-hari, berbeza dengan yang terjadi di antara pekerja pembinaan. Hal ini disebabkan oleh proses datangnya para TKI pembinaan cenderung berkelompok berdasarkan daerah asal; seperti TKI pekerja kilang dan khidmat kebersihan tinggal bersama-sama dengan sesama TKI dari pelbagai negara asal tanpa berkelompok-kelompok. Dengan begitu, mereka dapat tinggal di perantauan dengan lebih selesa kerana ada kumpulan orang-orang yang menghadapi pengalaman yang sama dan dapat berkongsi bersama-sama. Sementara itu, diketahui bahawa biasanya mereka datang berdasarkan cadangan dari TKI yang sudah lebih dahulu datang ke Malaysia dan biasanya diminta oleh majikan untuk mencari tenaga kerja pembinaan bagi keperluan projek. Dengan begitu, mereka cenderung tinggal berkelompok-kelompok berdasarkan etnik dan daerah asal.

Keadaan ini mengeratkan lagi hubungan dalaman etnik-etnik tertentu dalam kumpulan TKI di Malaysia. Sementara itu juga hubungan antara etnik pada kumpulan TKI ini juga terus kekal. Selain mengekalkan hubungan antara etnik dalam penghijrahan mereka di negara destinasi, informan TKI tetap membangun komunikasi dengan keluarga di negara asalnya. Komunikasi informan dengan keluarga mereka di tanah air menjadi satu hal penting dalam pengalaman mereka selama merantau, seperti berikut ini:

\title{
Komunikasi dengan Keluarga di Tanah Air
}

Selain mengekalkan budaya melalui kumpulan etnik mereka di negara destinasi, para informan TKI juga tetap menjalin komunikasi dengan kumpulan dalaman budayanya di negara asal. Penghijrahan tidak serta merta memutuskan jalinan komunikasi dengan orang-orang di luar kawasan negara destinasi penghijrahnya. Apatah lagi pada masa perkembangan teknologi sekarang ini, menghantar pesan ke kampung halaman bukan lagi satu hal yang sukar. Ketika ditanya apakah menghantar surat merupakan bagian daripada aktiviti yang dilakukan oleh informan untuk menjaga komunikasi dan berkirim khabar dengan keluarga di Indonesia, jawapan mereka adalah tidak. Daripada cara mereka memberikan jawapan terlihat bahawa berkirim surat sudah tidak lagi jadi bahagian daripada alternatif komunikasi yang mereka lakukan. Tentu sahaja, setiap informan pada kajian ini sudah mempunyai telefon bimbit sekurang-kurangnya satu unit. Dengan begitu, mereka lebih mudah untuk bertukar khabar dengan keluarga di tanah air.

\section{“...kalau isi telepon itu hari-hari habis lah. 30 (Ringgit Malaysia) habis lah...” (Yani- Khidmat Kebersihan)}

\section{“Kirim surat mungkin sudah nggak kepakelah, pake telepon.” (Dayu-Pembinaan)}

Biasanya informan membekali keluarga mereka dengan telefon bimbit untuk memudahkan berkomunikasi, sehingga mereka boleh bertukar khabar bila-bila masa sahaja diperlukan. Informan yang membawa suami atau isteri ke Malaysia pun demikian, biasanya mereka akan menelefon anak sekurang-kurangnya satu minggu satu kali. Tetapi kebanyakan dari mereka mengakui hampir setiap hari menelefon ke Indonesia. 
DOI: https://doi.org/10.47405/mjssh.v6i4.743

Menghubungi keluarga melalui talian telefon mahupun sentiasa berinteraksi melalui media sosial selalu dilakukan oleh setiap TKI. Para informan menyediakan belanjawan untuk komunikasi sekurang-kurangnya RM 10 setiap harinya. Hampir semua daripada mereka membuat panggilan ke Indonesia setiap hari, kadang-kadang boleh habis RM 10 untuk satu kali panggilan. Jika dikira, belanja mereka untuk keperluan komunikasi cukup besar jumlahnya, mencapai lebih kurang RM 300 setiap bulan. Belanja untuk komunikasi ini jumlahnya lebih kurang sama dengan wang untuk sewa rumah. Sehingga boleh dikatakan bahawa komunikasi ini menjadi salah satu keperluan asas informan.

$$
\begin{aligned}
& \text { “...satu bulan kalau saya habis } 300 \text { (Ringgit)” (Sri-Khidmatan Kebersihan) } \\
& \text { “...satu hari habis } 10 \text { Ringgit.” (Lela-Khidmatan Kebersihan) } \\
& \text { “...bisa habis } 50 \text { lebih lah.” (Heni-Khidmatan Kebersihan) }
\end{aligned}
$$

Pentingnya berkomunikasi dengan keluarga di tanah air menjadikan informan TKI ini sebagai pengguna telefon yang aktif. Bahkan mereka boleh membandingkan antara simcard yang jimat dan boros dalam pemakaian kredit.

“...Saya dua orang dengan istri saya tu, setelah pakai Tune Talk lebih kurang dalam tujuh puluh (Ringgit Malaysia) lah sekarang. Kalau dulu pakai Celcom, habis seratus (Ringgit Malaysia) lah.” (Abdul - Kilang)

“...Ada lagi sekarang U mobile. U mobile itu satu jam nelpon ke Indonesia sepuluh Ringgit. Tapi dari tarik satu sampai tarik dua puluh (Ringgit Malaysia) lah.” (BudiKilang)

Hubungan informan dengan orang-orang terdekatnya di tanah air sentiasa menjadi bahagian daripada kehidupan mereka sehari-hari. Penyelidik melihat meskipun informan secara fizikal berada di Malaysia, hidup di persekitaran orang-orang dengan budaya berbeza, bekerja di kawasan yang suasananya tidak sama dengan tempat mereka bekerja semasa di Indonesia, tetapi kehidupan mereka tidak sepenuhnya berada di negara destinasinya. Walau bagaimanapun, keluarga mereka masih lagi tinggal di Indonesia sehingga hubungan dengan keluarga di kampung halaman sentiasa dibangunkan dan menjadi bahagian daripada kebiasaan sehari-hari. Selain daripada itu, informan juga mengekalkan silaturahim dengan rakan-rakan yang ada di Indonesia dan sentiasa ikut dalam perkembangan maklumat terkini di tanah air.

Walaupun informan jauh daripada keluarga dan rakan-rakan di Indonesia, tetapi mereka tetap mengekalkan budaya asalnya selama berhijrah; menggunakan bahasa daerah asal, memakan makanan khas daerah asal. Kekerapan berkomunikasi ini seolah-olah menarik mereka daripada budaya tempatan di negara destinasi kepada kehidupan mereka di kampung halaman dan memberikan keselesaan yang tidak diperoleh dalam penghijrahannya. Dengan begitu, mereka boleh mengubati perasaan tidak selesa, kekecewaan atau ketidakpastian yang mereka temui di negara destinasi. Daripada pengalaman ini dapat disimpulkan bahawa hubungan budaya informan TKI dalam penghijrahan tidak hanya terhad pada kumpulan yang wujud di negara destinasi sahaja, tetapi juga terikat secara emosional kepada keluarga di negara asalnya.

Walaupun para informan terdedah dengan budaya tuan rumah dalam kehidupan sehari-hari, tetapi usaha untuk mengekalkan budaya sendiri juga dilakukan dengan tetap berada dalam kumpulan etnik budaya asal mereka. Menggunakan bahasa daerah dan bahasa ibu dalam komunikasi sehari-hari, memasak dan memakan makanan dengan cita rasa tempat asal, sentiasa berinteraksi dengan sesama pendatang dan tetap mengekalkan komunikasi dengan keluarga di kampung halaman membuat mereka terikat dengan kumpulan etnik dan budaya asal. Seterusnya adalah pengalaman interaksi dan komunikasi informan dengan masyarakat tuan rumah di negara destinasi, seperti berikut ini: 
DOI: https://doi.org/10.47405/mjssh.v6i4.743

\section{Interaksi dan Komunikasi dengan Masyarakat Tuan Rumah}

Sejak masih berada di negara asal, informan sudah membentuk persepsi mengenai negara destinasinya; mengenai budaya, orang-orang tempatan, pekerjaan yang akan didapatkan, kehidupan dan lain sebagainya sehingga pengalaman pra-penghijrahan mereka diwarnai oleh pengharapan. Seiring daripada perjalanan kehidupan seharian mereka di negara destinasi, informan mendapatkan pelbagai maklumat yang berasal daripada interaksinya dengan sesama penghijrah, interaksinya secara langsung dengan masyarakat tempatan, pemerhatiannya terhadap masyarakat tempatan dan daripada pendedahan kepada media massa.

Daripada pemaparan tersebut, penyelidik menghubungkaitkan dengan pengalaman informan di negara destinasi mengenai bagaimaan persepsi-persepsi yang terbentuk memberi kesan pada pengalaman seharian mereka. Daripada media massa yang biasa mereka baca, iaitu harian Kosmo!, informan membentuk satu pemahaman bahawa mereka akan kerap berurusan dengan pihak Polis apabila sedang berada di luar kawasan tempat kerja atau tempat tinggal. Sebutan seperti "Indon" atau "pekerja Indon" yang biasa mereka dengar dan baca daripada televisyen ataupun akhbar ternyata memberikan rasa takut dan waspada kepada diri mereka ketika sedang berada di luar kawasan tempat tinggal mereka. Seperti pengalaman yang disampaikan oleh informan setiap kali mereka pergi ke Kuala Lumpur, kerap kali mereka bertemu dengan Polis yang mendatangi mereka dan menanyakan kelengkapan dokumen yang mereka punya.

\section{"Kebanyakan yang ditakut semua orang dan saya itu adalah Polis di Malaysia.." (Medi- Pembinaan)}

"Kalau saya itu main ke sini (Kuala Lumpur) itu seperti di tempat asing, semuanya itu serba (tidak selesa). Dan, apa lagi yang itu, ketemu sama Polisi.” (Dayu-Pembinaan)

Daripada kisah pengalaman rakan-rakan yang pernah terjumpa Polis semasa mereka pergi ke Kuala Lumpur, menjadikan informan berhati-hati ketika bepergian. Pemberitaan mereka sebagai buruh asing yang bekerja di Malaysia melalui media telah membuat mereka digambarkan sebagai orang atau sekumpulan orang dengan ciri tersendiri. Stereotaip melekat kepada mereka sebagai pendatang haram, pekerja tanpa izin, belum lagi disyaki sebagai pelaku jenayah dan lain sebagainya membebani mereka selama berhijrah.

Kes yang terjadi kepada beberapa pekerja Indonesia yang tidak memiliki dokumen menjadi salah satu pelajaran yang diingat oleh informan sehingga mesti berhati-hati jika hendak bepergian ke bandar. Ditambah lagi pengalaman dari beberapa informan yang pada mulanya datang ke Malaysia tanpa dokumen lengkap dan bekerja berpindah-pindah membuat mereka lebih berhati-hati agar tidak mengalami hal yang tidak diinginkan. Daripada pengalaman yang mereka dengar dan pernah mereka alami sendiri, terkesan bahawa bila terlihat banyak pekerja asal Indonesia berkumpul di kawasan bandar, seolah-olah semua daripada mereka itu adalah pekerja haram. Hal ini tidak boleh dielakkan daripada wujudnya stereotaip seperti itu kerana sememangnya jumlah pekerja haram asal Indonesia banyak dan tidak boleh dijangka jumlahnya.

Melalui pengalaman sehari-hari TKI di negara destinasi, terbentuk pandangan-pandangan mereka ke atas masyarakat tempatan. Para pekerja sektor pembinaan pada asasnya mempunyai keinginan untuk boleh berinteraksi secara langsung dengan masyarakat tempatan. Tetapi, pada pengalaman sehari-hari, mereka merasa bahawa cara penduduk tempatan memandang mereka tidak bersahabat dan tidak menyambut mereka dengan baik. Pandangan itu seolah-olah mengisyaratkan bahawa kumpulan informan ini mungkin melakukan kejahatan ataupun tindakan jenayah. Selain daripada itu, kadangkadang orang tempatan menghindari untuk berpapasan di jalan dengan mereka, sehingga mereka menghindari dengan mengambil jalan yang lain. Sikap ini diterima informan pekerja pembinaan sebagai sikap yang tidak bersahabat, tidak menyambut mereka sebagai pendatang untuk memasuki persekitaran masyarakat tempatan dengan mesra. 
"Kalau orang sini, ya, kita pun susah. Datang kita senyum sama itu orang tempatan, dia ingat mau apa, gitu." (Ayub-Pembinaan)

"Jadi pun mau senyum sama orang sinipun susah lah. Dia ingat, mau apa? nanti dekatdekat dia repot, dia nak kacau kita, macam itu." (Uut-Pembinaan)

"Kalau kita senyum sekali dia gak balas, ya sudah tidak apa-apa. Kalau boleh diajak ngobrol, ngobrol, kita cuma mau berteman, kawan saja. Padahal di sini kan kita mau kerja, mau cari uang bukan mau cari masalah lah, di sini." (Medi-Pembinaan)

"Masalah interaksi memang sering, tapi kalau dia memang nanya kepada aku (kalau tidak ditanya maka tidak akan menyapa lebih dahulu). Tapi kalau nanya, bukan sok jual mahal tetapi segan." (Ayub-Pembinaan)

Para informan bersikap mempertahankan diri daripada dipandang yang negatif ke atas mereka. Mereka memutuskan untuk tidak berinteraksi secara langsung dengan masyarakat tempatan jika tidak diperlukan. Informan menyatakan bahawa jika tidak disapa. Sikap ini merupakan kesan daripada tindak balas yang diberikan oleh masyarakat tempatan kepada informan, sesuai dengan pengalaman mereka. Dalam perbincangan, informan kerap menanyakan pertanyaan adakah masyarakat tempatan mahu berinteraksi dengan mereka tanpa ada sangkaan apa-apa yang negatif terhadap mereka.

Mereka menyatakan bahawa tidak akan melakukan pendekatan terlebih dahulu dikeranakan rasa segan. Reaksi ini tentu tidak terjadi begitu sahaja, tetapi melalui beberapa kali pengalaman sehari-hari informan dengan masyarakat di negara destinasi. Dalam menyampaikan pandangan ini, mereka memberikan gerak isyarat yang menunjukkan rasa enggan untuk diperbincangkan lebih mendalam. Mereka membuat pernyataan yang kuat sehingga boleh diterima sebagai bentuk pertahanan diri daripada pandangan-pandangan yang tidak berkenan ke atas keberadaan mereka di negara destinasi.

Tempat tinggal TKI pekerja pembinaan yang kerap berubah-ubah sesuai dengan kawasan tempat mereka bekerja memungkinkan para informan untuk berada di sejumlah kawasan yang berbeza. Hal ini menyebabkan mereka mengalami pengalaman berinteraksi dengan masyarakat tempatan yang memiliki karakteristik pelbagai. Sementara itu, setelah habis bekerja pada petang hari, mereka punya masa yang banyak untuk dapat mengitari persekitarannya, mengenal kawasan tempat mereka bekerja. Saat itulah interaksi secara langsung, mahupun tidak langsung, terjadi antara informan dengan masyarakat tempatan. Masa berinteraksi lebih banyak berbanding informan yang bekerja pada sektor lain.

Dalam pengalaman para informan TKI, komunikasi boleh terjadi secara langsung ataupun tidak. Interaksi secara langsung adalah apabila informan secara langsung melakukan interaksi dengan masyarakat tempatan dalam wujud perbualan ataupun aktiviti di mana pertukaran pesan-pesan verbal dan tak verbal terjadi dengan sengaja ditujukan untuk satu sama lain. Sementara itu komunikasi tidak langsung wujud melalui pemerhatian di persekitaran terhadap masyarakat tempatan atau mendapatkan maklumat mahupun kisah daripada media massa atau penuturan rakan-rakan lainnya. Pengalaman ini tidak dialami oleh informan pekerja kilang dan khidmat kebersihan, hal ini mungkin disebabkan oleh representasi diri mereka di luaran yang berbeza dengan informan pekerja pembinaan. Pekerja kilang cenderung berpakaian dan berpenampilan lebih kemas berbanding pekerja pembinaan. Selain daripada itu, pekerja kilang tinggal di asrama yang mengehadkan interaksi mereka dengan masyarakat di luar kawasan asrama.

Para informan pekerja khidmat kebersihan juga pada asasnya memiliki peluang untuk berinteraksi dengan masyarakat tempatan di gedung-gedung atau kawasan tempat mereka bekerja. Kerana kawasan mereka cenderung permanen, jika dibandingkan dengan informan pekerja pembinaan, maka orangorang yang mereka temui pun relatif sama. Seperti informan pekerja khidmat kebersihan di Nilai dan Serdang ini, mereka akan bertemu dengan orang-orang menjadi pegawai di tempat mereka bekerja. Peluang untuk berinteraksi sangat banyak, tetapi hanya meliputi masyarakat tempatan yang bekerja di tempat itu sahaja, sehingga karakteristik orang-orang yang ditemui adalah terhad. 
Selain daripada itu, kerana tugas para informan ialah mengemasi dan membersihkan syarikat itu, interaksi secara langsung sangat mungkin terjadi seperti para pegawai kerap meminta pertolongan informan untuk mengemasi kubikelnya, membersihkan sesuatu atau membeli makanan pada waktu istirahat. Dengan begitu, ada hubungan yang baik antara pegawai, yang dimasukkan dalam kumpulan masyarakat tempatan, dengan informan sebagai pekerja pendatang. Interaksi seperti itu kadang-kadang tidak hanya berhenti sampai dengan pegawai memberikan arahan apa yang mesti dilakukan, dan informan mengerjakan apa yang diminta. Tetapi wujud juga perbualan-perbualan pendek yang boleh menjadi peluang untuk saling bertukar maklumat antara kedua-dua belah pihak; orang tempatan dan informan.

Daripada penuturan informan pekerja perkhidmatan kebersihan, didapati bahawa selama mereka bekerja, para pegawai bersikap baik kepada mereka. Tentunya ini juga tidak terjadi begitu sahaja, seperti diketahui bahawa informan sudah bekerja di tempat itu sekurang-kurangnya satu tahun. Selain daripada itu, informan sudah pernah bekerja di tempat yang lain untuk pekerjaan yang sama, sehingga sudah memiliki bekal mengenai bagaimana harus menghadapi orang-orang di tempat kerja. Mereka berpendapat bahawa orang-orang tempatan yang mereka temui, sama ada itu Melayu, Cina mahupun India, bersikap sangat baik kepada mereka. Kunci mereka hanya satu, bekerja dengan baik dan menjaga kepercayaan majikan.

Hal menarik daripada penuturan salah satu informan, yang disetujui oleh informan lainnya, mengenai bagaimana mereka mesti bersikap baik kepada siapa sahaja, dengan begitu orang lain pun akan baik. Menjadi kumpulan minoriti dengan imej dan stereotaip tertentu di negara destinasi bukanlah hal yang mudah untuk dilalui dengan bersikap baik sepenuh hati ketika berinteraksi dengan orang-orang di luar kumpulannya. Pernyataan para informan ini tidak wujud serta merta, melainkan berdasarkan pengalaman mereka bertahun-tahun bekerja dan berinteraksi selama berhijrah ini.

\section{"Kita baik, orang lain akan baik gitu saja. Kita jahat, orang lain akan jahat." (Wati- Perkhidmatan Kebersihan) \\ “...sedikit banyak kita mengambil (pelajaran dari) orang kaya yang masih menghormati kita yang bekerja sebagai pekerja cleaner. Ya macam kalau dekat kampung lah, ya tapi kebanyakan orang kaya itu bergaulnya dengan orang kaya saja. Macam itulah. Di sini saling menghormatilah. Itu saya suka. Walau pun dia kaya macam apa, tapi dia tetep menghormati kita, tetep menyapa, iya tetep menyapa kita hari-hari." (Parmi- Perkhidmatan Kebersihan)}

Bahkan, menurut penuturan para informan, masyarakat tempatan yang mereka kategorikan sebagai orang berpunya masih lagi menghargai mereka. Pengalaman ini tidak terlepas daripada bagaimana mereka membawa diri semasa bekerja dan berada di persekitaran masyarakat tempatan. Dari pengalaman sehari-hari, terkadang mereka diberi cendera hati, baju, atau barang-barang lainnya dari pegawai di tempat mereka bekerja. Biasanya, setelah ada perayaan di syarikat, informan pekerja khidmat kebersihan diberi makanan sehingga mereka merasa menjadi dihargai kerana bekerja lebih selepas aktiviti itu.

Kumpulan pekerja khidmat kebersihan seperti memiliki satu suara mengenai bagaimana masyarakat melihat dan memperlakukan mereka. Mungkin pandangan mereka sederhana, kerana pegawai boleh dikira selalu memberikan makanan atau barangan, sehingga masyarakat tempatan secara keseluruhan dinilai akan memiliki sikap yang sama. Dengan begitu, kesan informan pekerja khidmat kebersihan terhadap orang-orang lokal adalah baik. Walaupun ukuran interaksi yang baik tidak terletak pada seberapa sering seseorang memberi barang kepada orang lain, tetapi dengan latar kehidupan yang sedemikian, mereka sudah menganggap bahawa seiring masa berjalan, interaksi dengan masyakat tempatan tidak mengalami masalah yang berarti.

Berhijrah selama lebih daripada dua tahun telah membawa informan berada pada keterbiasaan dengan persekitarannya. Walau bagaimanapun, status mereka sebagai kumpulan minoriti yang secara sosio- 
ekonomi dipandang lebih rendah berbanding kumpulan majoriti, iaitu masyarakat tempatan, telah membangun dinding pemisah antara kedua-dua kumpulan masyarakat ini. Hal ini tidak boleh dielakkan walau serapat apa pun interaksi mereka dalam kehidupan sehari-hari. Kerana pada asasnya, informan dan masyarakat tempatan yang ditemuinya benar-benar berinteraksi masih dalam konteks profesional iaitu dalam lingkungan tempat mereka bekerja.

Daripada pemberitaan di media massa dan diperkukuh oleh kisah yang disampaikan oleh rakan-rakan sesama penghijrah dalam interaksi seharian TKI dengan masyarakat tuan rumah, membangun persepsi informan TKI mengenai penduduk tempatan, khasnya Polis. Informan merasa tidak terlalu bermasalah berinteraksi dengan masyarakat tempatan, tetapi selalu merasa tidak selesa bila berjumpa dengan Polis yang kerap melihat mereka seperti "pesalah".

Informan memahami bahawa stereotaip itu wujud kerana telah ada pengalaman atau kes sebelumnya terjadi terkait dengan dokumen pekerja yang tidak lengkap atau bahkan mereka tidak memiliki dokumen sama sekali, pekerja asing yang sudah habis pas pekerjanya, dan bahkan hingga kes jenayah yang dilakukan atau disyakin dilakukan oleh pekerja asal Indonesia. Pendedahan oleh media massa ke atas isu-isu itu secara berulang-ulang sehingga membentuk konstruksi pesan yang diterima oleh khalayak sebagai satu persepsi mengenai pekerja Indonesia. Daripada persepsi ini maka terbentuklah stereotaip yang wujud dalam masyarakat. Dengan begitu, kesedaran informan terbentuk mengenai bagaimana masyarakat tempatan melihat mereka daripada persepsi yang wujud dalam masyarakat itu. Hal ini memberikan kesan kepada bagaimana informan menghadapi persekitarannya.

Daripada pendedahan pengalaman interaksi dengan masyarakat tuan rumah, dapat diketahui bahawa setiap kumpulan informan menemukan kesukaran berinteraksi pada masa-masa awal penghijrahan. Berada dalam kumpulan budaya mereka dan berada di antara orang-orang dalam kumpulannya, membuat mereka selesa ketika menghadapi cabaran di negara destinasi. Jenis pekerjaan yang berbezabeza memberi kesan pada bagaimana mereka boleh berinteraksi dengan dunia luar. Selain daripada itu, jenis pekerjaan juga memberikan kesan pada bagaimana mereka merepresentasikan diri ke luar, sehingga wujud konstruksi imej, stereotaip dan bahkan prejudis ke atas mereka di kalangan masyarakat tempatan.

Selari dengan berjalannya waktu, para informan sudah mulai boleh melihat pengalaman semakan dokumen oleh polis di jalan-jalan di bandar itu sebagai sesuatu yang biasa dan tidak lagi menakutkan. Pengalaman yang menyebabkan rasa takut, kecemasan dan tidak selesa serupa ini juga wujud dalam interaksi seharian informan di negara destinasi sama ada itu interaksi dengan semasa pekerja penghijrah mahupun dengan masyarakat tempatan. Pada masa sekarang, perasaan takut itu sudah beransur-ansur hilang sebab sudah mulai terbiasa dengan keadaan persekitaran. Selain daripada itu, mereka juga sudah mulai terliterasi mengenai kepentingan dokumen, bagaimana pengurusannya, sudah merasa selesa dengan kumpulan sesama pekerja di kawasan tempat tinggal dan ini semua membawa kepada perkembangan interaksi mereka di negara destinasi.

Interaksi selama berhijrah ini bukanlah satu hal yang mudah, tidak pula sederhana. Interaksi selama berhijrah tidak hanya terjadi antara informan dengan orang-orang atau masyarakat yang ada di negara destinasi sahaja. Informan juga tetap berinteraksi dan menjalin komunikasi dengan sanak keluarga dan juga kawan rapat yang ada di Indonesia. Satu hal yang dominan nampak daripada sikap para informan mengenai interaksi dengan masyarakat tempatan adalah bahawa mereka mengehadkan tarikan kepada kumpulan di kumpulan budaya mereka untuk menghindari adanya konflik. Tetapi, hal ini boleh dilihat juga sebagai akibat daripada wujudnya prasangka sehingga mereka punya rasa khuatir jika tarikan mereka diterjemahkan sebagai suatu yang lain. Tetapi pada kes informan yang merupakan TKI di Malaysia ini adalah berbeza, justeru mereka cukup celik terhadap keadaan sekitarnya sehingga mereka mengehadkan atraksi diri tersebut.

Dalam berinteraksi dengan masyarakat negara tamu pula, informan TKI berinteraksi secara profesional dengan majikan dan orang-orang tempatan yang terbabit dalam pekerjaan mereka. Kedatangan TKI ke Malaysia telah memberikan persepsi tersendiri bagi masyarakat tuan rumah. Maklumat yang mereka peroleh daripada orang-orang di persekitaran dan pemberitaan media massa 
telah membawa mereka pada satu pandangan tertentu kepada para penghijrah. Ditambah pula latar budaya; bahasa, norma, kebiasaan, yang berbeza membuat interaksi di antara kedua-duanya agak sukar pada masa-masa awal penghijrahan.

“...awal-awal kerja di restoran memang susah beradaptasi. Dia orang (majikan) panggil kita 'budak', aduh, mau marah, mau pukul!' (Abdul-Kilang)

"Kalau di sini dipanggil 'budak indon', dulu, pertama saya masuk sini. Saya mau marah. Saya pikir, 'Ah, ini kerja.' Tapi lama-lama, udah dapat satu tahun, udah biasalah, dipanggil 'budak indon'. Tapi sekarang tak ada orang panggil 'budak indon'..." (Budi-Kilang)

“... 'Kamu orang indon, ya? O, patutlah.' Kan sakit hati kita pun, ya? Kayak apa gitu, aduh." (Didin - Kilang)

“Kayaknya sih, kita tu levelnya rendah banget, gitu." (Juju - Kilang)

Pengalaman-pengalaman yang disampaikan oleh para informan diikuti dengan raut muka yang menunjukkan rasa marah dan tidak suka. Nada suara mereka berubah agak ketus dalam menjelaskan bagaimana orang tempatan memperlakukan mereka. Beberapa istilah yang dipergunakan oleh majikan dalam memberi label kepada para TKI dianggap menghina. Tidak jarang daripada informan merasa marah ke atas label yang dipergunakan ataupun sikap yang ditunjukkan oleh majikan semasa waktu bekerja. Selari dengan waktu, kedua-dua kumpulan penghijrah dan majikan tuan rumah ini mulai memahami perbezaan bahasa satu sama lain, sehingga salah faham dalam berkomunikasi semakin dapat diatasi. Malahan, pada perbincangan kumpulan fokus yang dilaksanakan didapati bahawa informan TKI kerap menggunakan kata 'Indon' untuk menyebut 'Indonesia'. Ada kalanya seorang TKI akan menegur kawan yang menggunakan kata itu, tapi di lain waktu pula penyebutan 'Indon' untuk memendekkan penyebutan Indonesia dianggap wajar dan tidak bermakna apa-apa.

"Yang begitu pait itu (berinteraksi dengan) orang Melayu saja. Cuma orang Melayu itu pun masih keturunan Indonesia nenek moyangnya, dari dulunya...(Orang) Cina, India biasa saja. Kalau Cina, India tak begitu pait lah (dalam berinteraksi)." (Anton-Kilang)

Para informan TKI ini melihat bahawa cabaran dalam berinteraksi dengan masyarakat tempatan ditemui apabila bertemu dengan orang yang beretnik Melayu. Hal ini mungkin disebabkan kerana budaya kedua-dua kumpulan budaya ini terlampau dekat; berakar pada rumpun Melayu. Sementara itu mereka tidak menemukan masalah apabila berinteraksi dengan masyarakat tuan rumah yang beretnik Cina mahupun India. TKI pekerja Kilang cenderung berinteraksi dengan sesama penghijrah pekerja kilang juga, hal ini disebabkan mereka ditempatkan di asrama yang berisikan pekerja Kilang dari satu tempat kerja yang sama. Dengan begitu, mereka tidak punya untuk berinteraksi dengan masyarakat tempatan dengan lebih kerap.

"Kebanyakan. Bukan kebanyakan, semua di sini (yang tinggal di asrama adalah orang )Indonesia.” (Juju-Kilang)

“...kalau kami kan, kami udah di kilang. Kalau di kilangkan solah-olah terisolasi banget. Paling dengan orang tempatan yang kerja di sana. Saya rasa sih biasa." (Dini - Kilang)

Terlepas daripada pengalaman mereka ke atas stereotaip yang wujud dalam masyarakat tuan rumah, pada dasarnya mereka menganggap bahawa secara keseluruhan masyarakat tuan rumah baik dan boleh menerima mereka. Beberapa pengalaman yang kurang menyenangkan itu diakui terjadi pada masamasa awal penghijrahan. Dalam hal ini, mereka sebagai pendatang juga mungkin belum seberapa memahami budaya tempatan sehingga bersikap tidak sesuai dengan norma dan kebiasaan yang diamalkan di negara destinasi. 
Malaysian Journal of Social Sciences and Humanities (MJSSH), Volume 6, Issue 4, (page 21 - 36), 2021

DOI: https://doi.org/10.47405/mjssh.v6i4.743

"Sebenarnya mereka orang baik. Tapi macam, memandang kita tu rendahlah. Macam, gimana gitu. Ada apa-apa case, macam case apa, selalu di blow up, kan?" (Intan Kilang)

"Orang-orang sini kan sama, kayak orang Indonesia." (Sri-Kilang)

"Baik, mereka baik, kadang jumpa orang Indonesia, mereka tanya-tanya..." (Dini-

Kilang)

"Mereka (masyarakat tempatan) baik. Mereka menghormati kita. Baik-baik saja." (SriKhidmat Kebersihan)

“...iyalah, kadang-kadang orang office ya kadang panggil kita diajak pergi ke rumahnya.” (Dewi-Khidmat Kebersihan)

“...Di sini saling menghormatilah. Itu saya suka ...dia tetep menghormati kita, tetep menyapa, iya tetep menyapa kita hari-hari.” (Yani-Khidmat Kebersihan)

“...kalau orang Malaysia sendiri pergi ke Indonesia pun, dia pun mungkin sama. Dia pun mungkin saya di tempat lain pun harus begini, harus hormat juga. Kita di sini kan pendatang, kita pun harus menghormati orang lain." (Dayu-Pembinaan)

“...saya hari-hari (berinteraksi dengan) orang Malaysia. Tetangga saya orang Malaysia semua." (Wati-Khidmat Kebersihan)

“..Kita itu sebagai pendatang...Sebagai pendatang harus tahu diri.” (Abdul - Kilang)

Penyelidik mendapati bahawa para informan TKI faham keadaan di persekitaran. Mereka mengerti status mereka sebagai pendatang, pandangan tuan rumah ke atas mereka dan bahkan bagaimana media menyoroti setiap isu yang ada tentang TKI di Malaysia. Mereka tahu bahawa telah menjadi kewajiban bagi mereka untuk mematuhi aturan yang ada di persekitaran, bersikap baik dan mengamalkan budaya tempatan untuk dapat diterima dalam masyarakat.

“...Kalau kita senyum sekali dia gak balas, ya sudah gak papa. Kalau boleh diajak ngobrol, ngobrol, kita cuma mau berteman, kawan saja." (Medi-Pembinaan) “...masalah interaksi memang sering, tapi kalau dia memang nanya kepada aku.” (Ayik-Pembinaan)

“...Jadi pun mau senyum sama orang sinipun susah lah.” (Dayu - Pembinaan)

“...Kita hanya mau silaturahmi saja nggak bisa sama orang sini. Pandangannya kayak gimana kalau orang sini, gitu...”(Uut-Pembinaan)

Para informan terlihat sangat berhati-hati dalam memulai interaksi dengan masyarakat tuan rumah disebabkan oleh imej yang terbentuk ke atas mereka. Tetapi mereka juga tidak menyalahkan keadaan itu, sebab mereka tahu bahawa sebagai pendatang harus mengikuti norma dan aturan yang berlaku di persekitaran tuan rumah. Sementara itu, informan tuan rumah pula melihat bahawa para pekerja migran asal Indonesia ini sebagai orang asing yang tidak dikenali dan datang untuk bekerja di negara mereka. Untuk beberapa pekerjaan yang sifatnya domestik, TKI dilihat tidak terlalu berinteraksi dalam persekitaran sosial tuan rumah. Tapi berkenaan dengan TKI yang memiliki ruang bagi berinteraksi dalam masyarakat tuan rumah, mereka dilihat sebagai orang asing yang tidak boleh diajak untuk bergaul.

“...mereka tak berapa nampak macam social lah (tidak banyak bergaul).” (Matiarasu Majikan)

"...Masa itu saya pernah bergaul dengan dia (TKI), Apabila kita masuk ke daerah perladangan, saya jumpa dia orang bekerja di sana. " (Matiarasu - Masyarakat Umum) 
"...to be honest you, you, as Indonesian or whichever nationality you are, you cannot trust them a hundred percent. But when they show that they are interest to become your friend, they are willing to help you, and you also vice versa willing to help them..." (Izyan-Masyarakat Umum)

"...I akan merasa terganggu if there are too many of them sorrounding me. You go here you see Indonesian people, you go here you see Indonesian people. But as long as they don't, you know, they don't macam, they don't care about you, die tak kacau you, for me it's okay... A little bit uncomfortable because you never know what their gonna do" (Izyan - Masyarakat Umum)

“...Sekarang ni kan, kalau nak cakap kan, majority kan, memang ownernya orang Malaysia, tetapi selalunya, pelayannya, memang kebanyakan orang indonesia atau orang-orang lain kan, pekerja-pekerja dari pada negara lain. So far, sudah terbiasa lah..." (Wan-Masyarakat Umum)

Dalam interaksi antara TKI dengan masyarakat tuan rumah dapat dilihat terjadi secara tidak formal dan sifatnya tidak mesra. Masing-masing kumpulan masyarakat ini memahami keadaan persekitarannya di mana mereka harus berkongsi satu sama lain. Namun begitu, interaksi yang berlangsung membabitkan komunikasi di mana perkongsian maklumat telah membangun persepsi, stereotaip dan bahkan prejudis ke atas satu sama lain. Hal ini berkesan kepada jarak yang wujud antara kedua-dua masyarakat penghijrah dan tuan rumah.

\section{Kesimpulan}

Didapati bahawa interaksi dan komunikasi TKI dalam penghijrahan wujud antara sesama TKI penghijrah, antara TKI dengan keluarga di tanah air, antara TKI dengan masyarakat tuan rumah dan komunikasi melalui penggunaan media. Diketahui bahawa pendedahan ke atas media massa memberikan kesan ke atas pembentukan persepsi, stereotaip dan bahkan prejudis dalam interaksi sehari-hari. Sebagai kesannya, masyarakat tuan rumah cenderung membangun interaksi dengan TKI pada permukaan sahaja. Kesan daripada pengalaman bekerja di luar negara dihuraikan sebagai gambaran bagaimana mereka melalui pengalaman penghijrahan mereka di rantau dalam proses adaptasi antara budayanya.

\section{Rujukan}

Alberts, J. K., Nakayama, T. K., \& Martin, J. N. (2012). Human Communication in Society. New Jersey: Pearson.

Briandana, R. (2019). Television and National Identity: An Ethnography of Television Audience in the Border of Indonesia-Malaysia. Jurnal Ilmu Sosial dan Ilmu Politik, 23(1), 72-85.

Dementeva, S., Franzke, C. M., \& Loyko, O. (2015). Russioan-German Immigrants in Germany and Their Intercultural Communication. Procedia Social and Behavioral Sciences, 166, 516-520.

Firdausy, C. M. (2005). Trends, Issues and Policies Towards International Labor Migration: An Indonesian Case Study. United Nations Expert Group Meeting on International Migration and $\begin{array}{llll}\text { Development, New } & \text { York } & \text { 6-8 July }\end{array}$ http://www.un.org/esa/population/meetings/ittmigdev2005/P02-CMFirdausy.pdf [diakses 14 April 2014]

Fix, M., Papademetriou, D. G., Batalova, J., Terrazas, A., Lin, S. Y., \& Mittelstadt, M. (2009) Migration and the Global Recession: a Report Commissioned by the BBC World Service. Washington: Migration Policy Institute.

Gozzini, G. (2006). The Global System of Interntional Migrations, 1900 and 2000: A Comparative Approach. Journal of Global History, 1, 321-341.

Gsir, S. (2014). Social Interactions between Immigrants and Host Country Populations: A Country-ofOrigin Perspective. Research Report of European University Institute. 
Gudykunst, W., \& Kim, Y.Y. (1997). Communicating with strangers: an approach to intercultural communication Third Edition. Boston: McGraw-Hill.

Hugo, G. (2004). International Migration in Southeast Asia since World War II. Dlm. Ananta, A., \& Arifin, E. N. (pnyt.). International Migration in Southeast Asia, hlm. 28-70. Singapore: Utopia Press Pte. Ltd.

Hugo, G. J. (2006). Immigration Responses to Global Change in Asia: a Review. Geographical Research, 44(2), 155-172.

Ketab, S. M. G, Tamam, E., \& Bolong, J. (2015). Impact of Ethnocentrism on Interethnic Interactions among Local Students in Malaysian Universities. Taylor's Business Review, 5(2), 11-30.

Kholisoh, N. \& Sulastri, R. (2017). New Media Technology in Developing Effective Organizational Internal Communication. HUMANIORA, 8(1), 21-29.

Kim, Y. Y. (1977). Inter-ethnic and Intra-ethnic Communication: A Study of Korean Migrants in Chicago. Annual Meeting of the Western Speech-Communication Association, Phoenix, Arizona.

Kim, Y.Y. (1988). Communication and Cross-cultural Adaptation: An Integrative Theory. Clevedon: Multilingual Matters.

Kim, Y. Y. (2001). Becoming Intercultural. An Integrative Theory of Communication and CrossCultural Adaptation. Thousand Oaks, California: Sage Publications.

Kim, Y. Y., \& Bhawuk, D. P. S. (2008). Globalization and diversity: Contributions from Intercultural Research. International Journal of Intercultural Relations, 32, 301-304.

Klyukanov, I. E. (2005). Principles of Intercultural Communication. Boston: Allyn and Bacon.

Landis, D. (2008). Globalization, Migration into Urban Centers and Cross-cultural Training. International Journal of Intercultural Relations, 32, 337-348.

Lustig, M. W., \& Koester, J. (2013). Intercultural Competence: Interpersonal Communication Across Cultures Seventh Edition. New Jersey: Pearson.

Schierup, C., Hansen, P., \& Castles, S. (2006). Migration, Citizenship, and the European Welfare State. Oxford

Vertovec, S. (2007). Super-Diversity and Its Implication. Ethnic and Racial Studies, 30(6), 10241054.

Weiner, M. (1995). The Global Migration Crisis: Challenge to States and to Human Rights. Longman Publishing Group. 